\title{
ROMANTYCZNE METAFORY PAMIĘCI
}

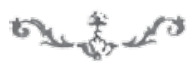

$\mathrm{W}$

IEK XIX jest często określany przez badaczy z nurtu memory studies jako punkt zwrotny w historii refleksji nad kategorią pamięci. Zmiana polegałaby, z grubsza rzecz ujmując, na tym, że wcześniejsze, ugruntowane już w starożytności rozumienie pamięci sprowadzało ten fenomen do czysto psychicznej funkcji przechowywania ${ }^{1}$ Pamięć traktowana była jako rodzaj zbiornika, w którym aparat psychiczny człowieka umieszczał spostrzeżenia i nabytą wiedzę. Przy takim rozumieniu pamięci możliwe było wykształcenie sztuki przypominania, czyli szeroko rozumianej mnemotechniki. Pamięć była tu traktowana jako czynnik jedynie wspomagający proces rozumienia; ważne było to, by nabyć umiejętność odtwarzania pierwotnie przyjętych wrażeń w postaci możliwie niezmienionej, a co za tym idzie - pokonać żywioł czasu i niszczenia. Tak rozumiana pamięć, jak wskazuje Aleida Assmann, była rodzajem sztuki (ars), od której wyraźnie odróżnia się pamięć ujmowana jako siła (vis). Ta dychotomia pojawia się w rozwiniętej postaci już u Giambattisty Vica, a później święci triumfy w filozofii Friedricha Nietzschego. Pamięć jest w tym ujęciu czynnikiem mającym istotny wpływ na tożsamość jednostki, jest zakotwiczona w czasie, a więc podatna na zakłócenie i zmianę:

W czasie następującym pomiędzy teraźniejszym działaniem a przyszłym przypomnieniem pamięć nie czeka cierpliwie w swoim bezpiecznym domostwie; posia-

1 Katalog owych funkcji można prześledzić w klasycznej już książce: F.A. Yates, Sztuka pamięci, przeł. W. Radwański, posł. L. Szczucki, Warszawa 1977. 
da własną energię i jest narażona na proces transformacji. Pojęcie vis przypomina nam, że w tym przypadku pamięć nie jest ochronnym zbiornikiem, lecz immanentną mocą, żywiołem kierującym się swoimi własnymi regułami. ${ }^{2}$

Ten pamięciowy zwrot jest szczególnie zauważalny w polskiej literaturze romantycznej, czy mówiąc ogólniej - w polskiej myśli pierwszej połowy XIX wieku. Pamięć może dalej funkcjonować w tym dawniejszym znaczeniu mnemotechnicznym, generalnie jednak zauważa się odwrót od wcześniejszych sposobów ujmowania pamięci, w tym oświeceniowych, pozostających pod silnym wpływem tradycji. Jednocześnie kultura polska zdaje się nieomal zainfekowana ideą upamiętniania, co pewnie najłatwiej dałoby się wytłumaczyć szczególną sytuacją historyczną, ale na przykład dla Adama Mickiewicza był to w ogóle rys wyróżniający narody słowiańskie ${ }^{3}$. Romantycy chcieli upamiętniać wszystko i pod możliwie każdą postacią, niekiedy aż do szaleństwa. Jeśli jednak przyjrzeć się obecnym w literaturze romantycznej metaforom pamięci, to większość z nich jest dosyć tradycyjna, konserwatywna bądź stereotypowa. Pojęcie „metafory pamięci” nawiązuje do ustaleń holenderskiego historyka psychologii Douwe Draaismy, który w książce Machina metafor ${ }^{4}$ postawił tezę, że historia pamięci jest niczym innym jak historią jej metafor, co wynika z faktu, że wszelkie próby bezpośredniego uchwycenia bądź opisu fenomenu pamięci zawsze kończyły się ugrzęźnięciem w pułapce językowych analogii. Teza Draaismy jest oczywiście naznaczona nietzscheańsko-derridowskim piętnem: jeśli się prześledzi, powiada autor, to, co od starożytności mówiono i pisano o pamięci, w rezultacie uzyska się rozległą i barwną panoramę różnorodnych przedstawień. Charakteryzują się one tym, że mówią nie tyle: „pamięć należy zdefiniować jako to a to”, ile raczej „pamięć funkcjonuje jak to

2 A. Assmann, Cultural Memory and Western Civilization. Functions, Media, Archives, Cambridge-New York 2013, s. 19-20.

3 „Ludy słowiańskie zdają się mieć szczególny dar pamięci, zamiłowanie do przeszłości. Przeszłości tej nie zmyślają sobie, nie tworzą sobie wyobrażenia o niej, ale - rzec można - ich imaginacja, zamieszkała w przeszłości, ma nieustanne i błyskawiczne jej wyczucie, i to w stosunku nie tylko do tradycji poetyckich, ale nawet do rzeczy bardziej powszednich i obojętnych" (A. Mickiewicz, WykładXX, w: tegoż, Dzieła. Wydanie Rocznicowe, t. 8: Literatura słowiańska. Kurs pierwszy, przeł. L. Płoszewski, oprac. J. Maślanka, Warszawa 1997, s. 273). Ideę, iż imaginacja może zamieszkiwać w przeszłości, dałoby się chyba wytłumaczyć tylko w ten sposób, że myślenie, działanie i tożsamość jednostki są pod nieustannym naporem przeszłych doświadczeń i w przeszłości zdobytej wiedzy. Mickiewicz odwołuje się więc tutaj do nowoczesnego rozumienia fenomenu pamięci. Kwestię stosunku polskiego romantyzmu do badań pamięci kulturowej podjął ostatnio między innymi Krzysztof Trybuś w książce Pamięć romantyzmu. Studia nie tylko z przeszłości (Poznań 2011).

4 D. Draaisma, Machina metafor. Historia pamięci, przeł. R. Pucek, Warszawa 2009. 
a to” albo „pamięć przypomina to a tamto”. Do dzisiaj jedną z powszechnie funkcjonujących w języku metafor pamięci jest „pamięć fotograficzna”. Jest ona metaforą, ponieważ aparat psychiczny człowieka nie jest aparatem fotograficznym. Warto również zdawać sobie sprawę, że to metaforyczne ujmowanie pamięci cechuje się swoistą zwrotnością; przykładowo dzisiaj myśli się o pamięci przy użyciu metafor komputerowo-digitalnych, a jednocześnie konstruuje się komputery i sieci w oparciu o to, co wiemy o ludzkich sieciach neuronowych. W tym kontekście wypada także dodać, że współczesne badania pamięci zbiorowej i kulturowej - zwłaszcza w kręgu niemieckojęzycznym - bazują na tezie, że namysł nad tak pojmowaną pamięcią przybiera nowy kształt i kierunek, ilekroć tylko zmieniają się jej technologiczne nośniki - cokolwiek by nimi było. W niniejszym tekście kontekst teoretyczny owych badań będzie miał jednak znaczenie marginalne.

Nie jest, jak się zdaje, przypadkiem, że w książce Draaismy romantyczne metafory pamięci znajdują właściwie tylko jedną reprezentację, mianowicie metaforę labiryntu Carla Gustava Carusa. Romantycy bowiem dość niechętnie używali w tym względzie porównań technologicznych; uważali pamięć za siłę czysto duchową, co najlepszy wyraz znalazło zarówno w polskiej literaturze, jak i filozofii mesjanistycznej, głównie u Karola Libelta. Najciekawszym bodaj wyrazem tego przekonania jest książka Zasady myśli i uczuć moich Floriana Bochwica z 1842 roku. Autor był ledwie rok młodszy od Mickiewicza i przez długi czas mieszkał w Nowogródku; zmarł zaś w rok po Mickiewiczu. Otóż u Bochwica odnajdujemy intrygującą wariację na temat „mitu pamięci absolutnej”. Nie używając tego terminu, przywołuje ideę, która intrygowała nie tylko filozofów, nie tylko pisarzy w rodzaju Jorge Luisa Borgesa (autora $\mathrm{Pa}$ miętliwego Funesa), ale również psychologów, psychiatrów i psychoterapeutów (Sigmund Freud i jego „magiczna tabliczka”), a także biologów, neurologów i psychoneurologów (przykładem jest Aleksander Łuria, autor Umysłu mnemonisty). Jeszcze w XX wieku próbowano udowodnić tezę, że człowiek niczego nie zapomina. Bochwic, prawnik i filozof, oferuje nam mit pamięci absolutnej à rebours: podczas gdy neurolog zająłby się dowodzeniem, że pamięć absolutna może być zagwarantowana tylko przez swoją materialną podstawę (neurony albo niektóre części mózgu, takie jak hipokamp), Bochwic stwierdza, że właśnie dlatego, iż pamięć człowieka żyjącego skażona jest materialnością i zmysłowością, bywa ona ułomna. A mimo to człowiek niczego nie zapomina. Argument za tą tezą odnajduje Bochwic w sferze ducha:

Pamięć omroczona za życia ziemskiego zmysłowością i materią zostanie oczyszczoną i wyjaśnioną w przyszłym: z mniejszą dokładnością we zwierciadle odbijają się przed- 
mioty, niż ukażą się w pamięci wyryte obrazy świata, ludzi, wydarzeń i przeszłej myśli własnej, uczuć i postępków; nic z niej stracone być nie może. ${ }^{5}$

Pamięć zapisuje więc wszystko, ale nie w materiale cielesnym, który stanowi przeszkodę w odtworzeniu zapamiętanej treści, lecz w duszy. Jak pisał mniej więcej w tym samym czasie francuski teolog katolicki Jean-Joseph Gaume, „pamięć jest to dusza pamiętająca”. Obaj autorzy są oczywiście zadłużeni w neoplatońskiej refleksji św. Augustyna, który uważał, że pamięć jest częścią duszy, a nawet jest tożsama z duszą, daleko im jednak do złożoności i komplikacji, do jakich autora Wyznań prowadzi analiza fenomenu pamięci, w szczególności w jej związku ze świadomością i tożsamością jednostki. Jesteśmy tu w każdym razie jak najdalej od fizjologicznych czy materialnych objaśnień pamięci, które w szczególności były domeną poprzedników (nauka oświeceniowa) i następców (pozytywizm). Przykładowo, Jędrzej Śniadecki uważał, że wrażenia i wyobrażenia „[...] pozostają w nas, wzbudzając odpowiednie poruszenia w miazdze nerwowej [...]. Władzę odnawiania pewnych poruszeń mózgowych i do nich przywiązanych uczuć nazywamy pamięcią"” . A już szczególnie mocno oddalamy się od koncepcji Ludwiga Büchnera, którego Siłę i materię z 1855 roku wydano również po polsku (1869). Twierdził on, że „pamięć może

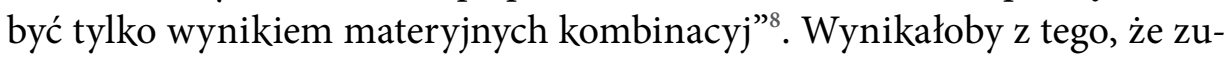
pełnie pozbawiona sensu i naukowego wsparcia jest teza o istnieniu trwałej i niezmiennej pamięci; materia ulega ciągłym przekształceniom i zmianom, z czego wynika, że temu samemu musi podlegać i pamięć. Wypada w tym miejscu dodać, że Büchnerowski materializm spotkał się z dość radykalnym sprzeciwem, co nie zmienia faktu, że romantyczne myślenie o pamięci przeplatało się w refleksji europejskiej z różnego rodzaju objaśnieniami materialistycznymi, zwłaszcza z frenologią Franza Josepha Galla.

Jak to już zostało zasugerowane, romantyczne metafory pamięci są w znacznej mierze dosyć tradycyjne i z reguły dobrze zakotwiczone w historii filozofii i literatury. Ich korzenie sięgają starożytności, a najpóźniej średniowiecza. To oczywiście mówi niemało o „cywilizacji” romantyzmu. Niniejszy

5 F. Bochwic, Zasady myśli i uczuć moich, Wilno 1842, s. 133.

6 J.J. Gaume, Zasady i całość wiary katolickiej, czyli wykład jej historyczny, dogmatyczny, moralny, liturgiczny, apologetyczny, filozoficzny i socjalny, od stworzenia świata az do naszych czasów, [przeł. L. Rogalski], t. 1, Kraków 1870, s. 149.

7 J. Śniadecki, O fizycznym wychowaniu dzieci, Warszawa 1840, s. 106. Przekonanie Śniadeckiego, że pamięć pozwala przywrócić „to samo uczucie i to samo poznanie”, a więc pierwotne wrażenie czy postrzeżenie, pozostaje w orbicie tradycyjnej koncepcji pamięci-magazynu.

8 L. Büchner, Siła i materia. Filozoficzne studia na polu doświadczeń przyrodniczych, przeł. L. Mulski [L. Mikulski], Lwów 1869, s. 92. 
artykuł nie rości sobie jednak pretensji do jakichś uogólniających tez i ustaleń. Będzie raczej formą przeglądu albo katalogu, pozbawionego na dodatek jakiejś wiążącej konkluzji. Proponuję zatem prześledzić wpierw owe zastane metafory, by na koniec dopiero wskazać kilka innowacji i „odstępstw”.

(1) pamięć jako woskowa tabliczka

Metafora ta nie posiada być może bogatej reprezentacji tekstowej, ale wymieniam ją na początku przez wzgląd na jej historyczno-filozoficzne pierwszeństwo - pojawia się oczywiście w znanym fragmencie Platońskiego Teajteta. Filozof i psycholog Michał Wiszniewski w swoich Charakterach rozumów ludzkich (1837) powiada tak: „Człowiek rozumny miewa łatwe pojęcie i wierną pamięć; przyjmuje wrażenia łatwo jak wosk, a zachowuje upornie, jak marmur [...]" ${ }^{9}$. Moglibyśmy stwierdzić, że Wiszniewski konstruuje nową wersję tej klasycznej metafory, poszerzoną o kwestię trwałości zapamiętanych wrażeń (opozycja wosku i marmuru); moglibyśmy - gdyby nie fakt, że mamy tu do czynienia z kryptocytatem z George'a Gordona Byrona i jego weneckiego poematu Beppo, w którym padają następujące słowa: „His heart was one of those which most enamour us, / Wax to receive, and marble to retain [...]" ${ }^{10}$.

Do metafory tabliczki woskowej autorzy z pierwszej połowy dziewiętnastego stulecia odnoszą się zazwyczaj z rezerwą, jeśli nie krytycznie. Przyczyna wydaje się prosta - odcisk w wosku zakłada istnienie materialnej bazy, w której zewnętrzne wrażenie mogłoby pozostawić swój ślad, a samo odciskanie ma charakter wybitnie fizyczny czy cielesny. Nawet ci, którzy proponują wyjaśnienia o charakterze fizjologiczno-psychicznym - jak Mikołaj Lipiński, lwowski profesor filozofii, w swoim Zarysie antropologii psychicznej, czyli psychologii empirycznej dla użytku dojrzalszej młodzieży polskiej (1867) - uznają metaforę wosku za skrajnie materialistyczną i z tego względu nie wytrzymującą krytyki, która niekiedy zmierza ku ekstremum: jak powiada biskup Michał Korczyński w redagowanym przez siebie przemyskim czasopiśmie „Przyjaciel Chrześcijańskiej Prawdy”, pamięć jest władzą czysto duchową. Wypowiedziana tu

9 M. Wiszniewski, Charaktery rozumów ludzkich, Kraków 1842, s. 190.

10 G.G. Byron, Beppo. A Venetian Story [online], Genius [dostęp: 2015-10-2o]: <http://genius.com/George-gordon-byron-lord-byron-beppo-annotated/>, strofa XXXIV. Podobną ideę znajdujemy na długo przed Byronem, mianowicie w Cyganeczce Miguela de Cervantesa, gdzie młody adorator tak sławi wdzięki Preciosy: „[...] ale wobec niej z wosku jest moja dusza, na której wszystko, co zechce, będzie mogła wycisnąć, a kiedy przyjdzie zachować ślady jej dłoni, wosk stanie się marmurem, którego twardość działaniu wieków opór stawia" (M. de Cervantes, Nowele przykładne, przeł. Z. Milner, Warszawa 1949, s. 33). Wiszniewski obu autorów zna, na każdego z nich powołuje się w swojej książce. Niewykluczone oczywiście, że tradycja tej opozycji jest znacznie dłuższa i że z niej czerpią zarówno Cervantes, jak i Byron. 
religijna idea niczym właściwie nie różni się od cytowanych już przekonań Bochwica i Gaume'a:

Tej pamięci władzy nie nadaje nam serce, ani mózg, ani krew, ani atomy jakieś, ale ją posiada duch jakiś, duch boski. Śmiesznością byłoby rozumieć, że pamięć tych rzeczy odciska się, czyli wytłacza na mózgu, jak na wosku, bo mogąż słowa, myśli ślady jakieś zostawić na duszy lub na mózgu, i jakiejże by to potrzeba szerokości i wielkości mózgu, by na nim tyle wyryć przedmiotów? ${ }^{11}$

Krytyce fizjologicznych objaśnień pamięci towarzyszy tu coś, co można by określić jako przyczynek do ekonomii pamięci. Mianowicie wielu spośród tych, którzy o niej pisali i piszą, dręczyło następujące pytanie: jak można w aparacie psychicznym pomieścić tak wiele wrażeń i dodawać do niego wciąż nowe? Metaforycznym rozwiązaniem problemu owej „szerokości i wielkości mózgu” będzie chronologicznie późniejsza, daleka - rzecz jasna - od jakiejkolwiek religijnej duchowości, Freudowska magiczna tabliczka, która ilustruje jednoczesny gest dopisywania, wymazywania i przechowywania ${ }^{12}$.

\section{(2) pamięć jako (otwarta) księga}

Ta metafora o średniowiecznym rodowodzie - jako wariacja na temat księgi natury - cieszyła się wprost niebywałą popularnością wśród romantyków. W tekstach literackich z pierwszej połowy XIX wieku określenia „księga pamięci”, „księga wspomnień”, „księga pamiątek” (czasem w formie zdrobniałej - „książka”) występują nieomal ciągle. Dość przypomnieć księgę herkulańską z III części Dziadów, metaforę o tyle szczególną, że z tej konkretnej księgi trudno cokolwiek wyczytać ${ }^{13}$, podczas gdy księgi pamięci to $\mathrm{z}$ reguły księgi otwarte, dający łatwy i przejrzysty dostęp do zdeponowanej w nich wiedzy. Popularność tej metafory można również wytłumaczyć rozplenieniem się sztambuchów i pamiętników, które były namacalnymi księgami pamięci, choć mogło być i na odwrót - pamiętniki i sztambuchy zaczęły się plenić przez wzgląd na siłę i nośność metafory. W rezultacie każdy, kto wpisywał się do sztambucha, wpisywał się do księgi pamięci w dwojakim sensie: zarówno do pamięci ludzi, jak i do tej faktycznej książeczki, która ludzką

11 M.K. [Michał Korczyński], O zacności i nieśmiertelności duszy, „Przyjaciel Chrześcijańskiej Prawdy. Czasopismo teologiczne [...]” 1835, z. 2, s. 13.

12 Zob. Z. Freud, Uwagi o magicznej tabliczce, przeł. Z. Rosińska, w: Pamięć w filozofii XX wieku, pod red. Z. Rosińskiej, Warszawa 2006.

13 Zob. A. Mickiewicz, Dziady. Część III, w: tegoż, Dzieła..., t. 3: Dramaty, oprac. Z. Stefanowska, Warszawa 1999, s. 206. Księga jest nie do odcyfrowania, ale tylko w swoim wymiarze ziemskim - jej autorem i jednocześnie modelowym czytelnikiem jest Bóg („On to wszystko zapisał, wszystko mnie opowie”). W tym sensie metafora użyta przez Mickiewicza tylko częściowo odbiega od tradycji. 
pamięć miała wspomagać. Sztambuchy i pamiętniki były więc nazywane „księgami pamięci”. Tak więc na przykład Kornel Ujejski we wpisie sztambuchowym stwierdza: „O Polko! Polko! na cóż mam tobie / W księdze pamięci me imię ryć [...]”14. Józefina Osipowska: „Z gór nadniemeńskich oderwane Echo / Lecę się trącić o księgę pamiątek!” ". Nieznany autor o inicjałach A.K.: „Niosę Ci rymy moje do księgi pamięci / Niechże i ja tam będę, gdzie są wszyscy święci"16.

Metafora księgi występowała często w formie blisko spokrewnionych metafor znamionujących pismo. W największym skrócie chodziło o to, by zapisać się nie tylko na kartach sztambucha, ale przede wszystkim „sercem w przyjaznej zapisać pamięci” (Julian Korsak) ${ }^{17}$. Ten związek z sercem albo czuciem prowadził zresztą niejeden raz do podważenia samej metafory księgi pamięci. Tak jak Platoński Fajdros stanowi fundamentalną krytykę pisma, któremu przeciwstawiona zostaje filozoficzna idea rozmowy w wąskim, zaufanym kręgu, tak i romantycy sugerowali, że księgi, litery, pismo, druk noszą piętno śmierci, chyba że zostaną wskrzeszone siłą serca, czucia albo ducha. Znamienne przykłady znajdujemy u Maurycego Gosławskiego i Hieronima Feldmanowskiego. Oto wyjątek z drugiego z nich:

Mam pisać dla pamięci? Wiesz co to pamiątki?

Pani! to prochy uczuć, zwiędłych kwiatów szczątki,

Nagrobki dni minionych z żywych barw odarte,

Cacka drogie a martwe, jednej łzy niewarte!

Lecz połóż je na sercu, ożyw jego tchnieniem,

Do wyobraźni zanieś skrzydlatym wspomnieniem

I oświeć twoich uczuć latarnią magiczną

A ujrzysz na tle duszy ich barwę prześliczną.

Obaczysz, jak się złożą w przecudne obrazy,

Żyjące i mówiące na twoje rozkazy [...]. ${ }^{18}$

\section{(3) pamięć jako ogród}

Metaforę tę, podobnie jak metaforę księgi, często można znaleźć we wpisach sztambuchowych. O ogrodzie pamiątek mówi w pamiętniku Marii Siwickiej sam Mickiewicz - przy czym rzeczonym ogrodem jest ów pamiętnik ${ }^{19}$.

14 Cyt. za: A. Biernacki, Sztambuch romantyczny, wyb. i oprac. A. Biernacki, wstęp M. Dernałowicz, Kraków 1994, s. 233.

15 Tamże, s. 292.

16 Tamże, s. 347.

17 Tamże, s. 101.

18 Tamże, s. 350.

19 Por. Tamże, s. 112. Identyczną ideę (sztambuch jako ogród, miejsce wpisu - „mały zakątek” w tym ogrodzie) znajdujemy we wpisie Antoniego Czajkowskiego (tamże, s. 216). 
Z kolei Paszkowski (być może był to Józef Paszkowski) pisze: „Udeptaną koleją śpieszę za innymi / Po drożynie wiodącej do twojej pamięci [...]”2o, co z jednej strony kojarzy się z ideą wędrówki, z drugiej zaś - może przywodzić na myśl ideę ogrodu, a nawet labiryntu. Pamięć może być w tym ogrodzie czy labiryncie drogowskazem, a ściślej rzecz biorąc - i to kolejna metafora - kompasem. O kompasie pamięci mówi na przykład Julian Korsak ${ }^{21}$. Nie trzeba oczywiście dodawać, że kompas nie stanowi tutaj o nowoczesności (w sensie cywilizacyjnym) tej metafory. Urządzenie to zostało wynalezione w Chinach około II wieku p.n.e., a później, gdzieś na początku XIV wieku, udoskonalone w Europie. W pracy Aurelego Urbańskiego Dusza ludzka a dusza zwierzęca. Studium psychologiczne (1866) pamięć zostaje zwizualizowana poprzez porównanie $\mathrm{z}$ kompasem i barometrem - oba są tym, co pozwala poruszać się w świecie. Urbański daleki jest jednak od romantycznej wzniosłości. Za fenomeny szczególne, przynależne jedynie istotom ludzkim, uznaje on zdolność myślenia i rozumowania; barometr pamięci może być natomiast w równym stopniu rozwinięty zarówno u ludzi, jak i u zwierząt, a nawet z przewagą tych ostatnich ${ }^{22}$.

Metafora ogrodu w jednym ze swych znaczeń wydobywała wysiłek pielęgnowania pamięci, w innym zaś - wielotorowość, wielowątkowość, jakimi może podążać pamięć. Wpisuje się równocześnie w romantyczną ideę jedności krajobrazu i ducha, znamienną choćby dla Carla Gustava Carusa i Caspara Davida Friedricha.

\section{(4) pamięć jako zwierciadło}

Metafora zwierciadła bądź lustra znalazła wyraz w cytowanym wcześniej traktacie Bochwica, który - przypomnę - sądził, że wraz z pozbyciem się cielesnej szaty to, co wyryte w pamięci, zobaczymy lepiej niż w zwierciadle. Oczywiście, słyszymy tu echo słów św. Pawła ${ }^{23}$ - nie będzie zaskoczeniem, jeśli dodam, że w X księdze Wyznań te słowa przywołuje również św. Augustyn. Nie może istnieć dokładniejsze odbicie niż w zwierciadle duszy. Konotacje religijne pozwalały przechodzić obojętnie obok zasadniczej wady tej metafory: nie tłumaczyła ona w żadnej mierze, jak pamięć może utrwalać i przecho-

20 Tamże, s. 280.

21 Zob. J. Korsak, Elegia XIV. Wieczór, w: tegoż, Poezje, Petersburg 1830, s. 69.

22 A. Urbański, Dusza ludzka a dusza zwierzęca. Studium psychologiczne, „Biblioteka Ossolińskich. Pismo historii, literaturze, umiejętnościom i rzeczom narodowym poświęcone” 1866 , t. 9, s. 309-311.

23 "Teraz widzimy jakby w zwierciadle, niejasno; / wtedy zaś [zobaczymy] twarzą w twarz” (1 Kor 13, 12); cyt. za: Pismo Święte Starego i Nowego Testamentu w przekładzie z języków oryginalnych, oprac. zespół biblistów polskich z inicjatywy Benedyktynów Tynieckich, Poznań 1991, s. 1302. 
wywać wrażenia. A jeśli zwierciadło, to i swoisty „protolacanizm”: przeglądając się w zwierciadle pamięci, mielibyśmy się mierzyć $\mathrm{z}$ wystawionym tam - domyślnie lepszym - wizerunkiem przeszłości. Przykładowo, Łukasz Gołębiowski stwierdza we wpisie sztambuchowym, że przeszłość „[...] ma być zwierciadłem, gdzie się odbija cecha ich [potomków, następców - G.M.] rodu, gdzie upatrywać mają drogi postępu, udoskonalenia” ${ }^{24}$. Ciekawą wersję tej metafory znajdujemy we Wspomnieniach z podróży do Syberii, pobytu $w$ Berezowie i Saratowie (1852) Ewy Felińskiej:

Gdyby nie uczucia tlejące w głębi, gdyby nie zwierciadło pamięci odbijające przeszłość tak żywymi barwami, cóżby mi świadczyło o tożsamości mojej istoty?

Tu mi się nastręczyło pytanie: Czy możność przechowania pamięcią na dnie duszy dawnych wrażeń jest dobrodziejstwem czy też przeciwnie? Prędko odrzuciłam precz to pytanie, bałam się bluźnierstwem skalać myśl moją. Jeżeli przeszłość umarła, tak przywrze pamięcią do duszy, że ani oderwać jej nie można, ani wskrzesić niepodobna, to ciężko, bardzo ciężko! Wszakże jest to jedyna część, w której choć się ból czuje, ale tleje życie; reszta śmierć, próchno. ${ }^{25}$

To obrazoburcze pytanie jest właściwie pytaniem antyromantycznym, jeśli nie antypolskim - o ile przez romantyczny, jak sugeruje to Konrad Wallenrod (określany przeze mnie mianem „pamięciomatu”), należy uznać obowiązek ustawicznego pamiętania. By zażegnać wiążące się z tym niebezpieczeństwo, Felińska odwołuje się więc do romantycznego przekonania, że nie pamiętać znaczy to samo, co umrzeć; niepamięć to jedna $z$ twarzy śmierci. Paradoks albo pozorny paradoks, którego nie będziemy tu rozważać, a który jedynie zasugerujemy, polega na tym, że w przywołanym fragmencie iskierkę życia odnajduje się w przeszłości umarłej; aby więc uciec przed śmiercią, trzeba zwrócić się ku temu, co samo padło jej łupem.

\section{(5) pamięć jako miejsce święte (świątynia, kościół)}

Literatura romantyczna lubowała się w tego typu metaforyce i analogiach. Znamienną i dobrze znaną definicję odnajdujemy w Konradzie Wallenrodzie: „O pieśni gminna, ty stoisz na straży / Narodowego pamiątek kościoła [...]”26. Jednakże romantycy nie byli tu żadnymi innowatorami, odwoływali się bowiem do wcześniejszych tradycji, które ujmowały pamięć w kategoriach sakralnych. Przedromantyczne jest w szczególności opisywanie pamięci jako

24 Cyt. za: A. Biernacki, dz. cyt., s. 314.

25 E. Felińska, Wspomnienia z podróży do Syberii, pobytu w Berezowie i Saratowie, t. 1, Wilno 1852, s. 122.

26 A. Mickiewicz, Konrad Wallenrod, w: tegoż, Dzieła..., t. 2: Poematy, oprac. W. Floryan przy współpracy K. Górskiego i Cz. Zgorzelskiego, Warszawa 1998, s. 101. 
zamkniętej przestrzeni, co w oczywisty sposób odnosi się do mnemotechnicznej idei, zgodnie z którą pamięć stanowi rodzaj zbiornika czy magazynu. Świątynia pamięci kojarzy się również wprost - z należącą do tej samej przedromantycznej tradycji - koncepcją pałaców pamięci. Wypada przypomnieć, że świątynia Sybilli w Puławach, gdzie Izabela Czartoryska gromadziła najprzeróżniejsze pamiątki po rodzinie i sławnych Polakach, pierwotnie była zwana Świątynią Pamięci. Jak powiadał książę Adam Kazimierz Czartoryski, jedną z dróg prowadzących do świątyni pamięci, rozumianej tym razem jako wdzięczna pamięć potomnych, jest „gościniec nauki”, co oznacza, że egzorcyzmowany przez romantyków rozum nie kłóci się z sakralnym charakterem pamięci. Zresztą nie tylko pamięć jest świątynią; święte są pamiątki i różnego rodzaju upamiętnienia. Niekiedy - robi tak chociażby Gołębiowski - łączy się różne metafory, w tym przypadku metaforę sakralną i metaforę księgi: przeszłość „dla następców świętą powinna być księgą, w której czytają przodków swych czyny, słowa ich słyszą [...]”27. Zarówno autorzy oświeceniowi, jak i romantyczni nieomal epigońsko rymują słowa "pamięci” i „święci (się)” albo „uświęci”.

W orbicie tej metafory pozostaje pewien specyficzny ładunek uczuciowy, jaki romantycy często łączyli z pamięcią. Nader chętnie bywa ona bowiem ujmowana w tonacji posępnej, ciemnej, żałobnej, wręcz cmentarnej. Na tytułowe pytanie: Dlaczego pan taki smutny? Seweryn Grzegorz Filleborn odpowiada: „Smutnym, bo mnie w tej chwili twa wesołość smuci, / Pusta radość bez myśli, bez pamiątek chwile [...]”28. Za świadomością bólu wiążącego się z pamięcią szło pragnienie pamiętania oraz wspominania i to dwuznaczne połączenie znalazło doskonały wyraz w przywołanych wspomnieniach Felińskiej. Można przy tym mówić o niezwiązanej bezpośrednio z pamięcią, ale często w kontekście pamięci pojawiającej się estetyce smutku czy cierpienia - zawierającej przesłanie, że smutek upiększa. Przykładowo, Franciszek Morawski napisał w sztambuchu:

\author{
O Polki! Polki! Słynna piękność wasza \\ Nie jest w tych wdziękach, które świat rozgłasza: \\ Waszym urokiem jest wryta źrzenica, \\ Smutkiem niedoli umilone lica; \\ Owe bolesne i długie dumania \\ Gdzieś tam krążące po krajach wygnania;
}

27 Cyt. za: A. Biernacki, dz. cyt., s. 314. Fragment ten wiąże się z wcześniej cytowanymi słowami Gołębiowskiego, w których wprowadza on kolejną metaforę - zwierciadło.

28 S.G. Filleborn, Dlaczego pan taki smutny?, w: Zbiór poetów polskich XIX w., ułożył i oprac. P. Hertz, ks. 2, Warszawa 1961, s. 767. 
Ów wzrok, co blaskiem łzy cnotliwej płonie, Błądzi po grobach lub też w gwiazdach tonie. ${ }^{29}$

(6) pamięć jako ogień, żar, płomień

Ten typ metaforyki popularny był nie tylko w romantyzmie i przed romantyzmem - żywotność zachował aż do dzisiaj i nie trzeba dodawać, że jego zewnętrzną manifestacją są przede wszystkim cmentarne znicze jako symbol naszej pamięci. Te metafory ujmowane były często - i są ujmowane po dziś dzień - w formułę negatywną: wtedy, gdy mówi się, że pamięć nie gaśnie albo nie może zgasnąć. „Nie wygasła u nich pamięć dawnej ojczyzny” - to sformułowanie zaczerpnięte z Dziejów starożytnych narodu litewskiego (1835-1845) Teodora Narbutta ${ }^{30}$ pojawiało się w relacjach historycznych - czy jak w przypadku Narbutta legendarno-historycznych - po wielokroć. W dzisiejszej Polsce metafora ta powróciła do przestrzeni publicznej, gdy w 2011 roku władze Warszawy podjęły decyzję o usunięciu sprzed Pałacu Prezydenckiego zniczy upamiętniających katastrofę smoleńską. W prasie prawicowej i konserwatywnej ten dosłowny akt był odczytywany jako akt o szczególnej doniosłości symbolicznej: akt gaszenia pamięci. Publicysta Igor Janke pisał:

Platforma próbuje więc, jak może, gasić naszą pamięć. Problem w tym, że to praktycznie niemożliwe. W tym kraju pamięci nie da się zgasić. Nie dało się nigdy w przeszłości, nie da się i teraz [...]. Taka akcja jak ta z marcowej nocy [usuwania zniczy - G.M.] wywołuje nie tylko ból, ale i wściekłość. Pobudza ludzi do działania. ${ }^{31}$

Płomień lampki - czy będzie to znicz, kaganek, lampka oliwna czy lampka wieczna, którą umieszcza się w tabernakulach - zawsze w mniej lub bardziej oczywisty sposób odnosi do sfery sacrum. Gdy pamięć jest rozumiana jako płomień czy żar, to raz jeszcze potwierdza się jej quasi-sakralny charakter. Przyjmuje on niekiedy eksplicytnie religijną postać: „Szczęśliwy, w czyim sercu zapalono / Lampę pamiątek Chrystusa ofiary"32.

Pamięć bywała jednak niejednokrotnie opisywana w radykalnie odmienny sposób - jako lodowaty chłód. Na przykład Dyzma Bończa-Tomaszewski porównuje dwa wymienione w tytule swojego utworu zjawiska: wyobraźnię i pamięć. Stwierdza tam, co następuje: „Pierwsza jest żywa, ognista i wspaniałomyślna, druga zimna i metodyczna. Dla pamięci potrzeba, aby wszystko przeszło i wszystko umarło, dla wyobraźni, aby się wszystko rodziło i ożywiało" ${ }^{33}$.

29 Cyt. za: A. Biernacki, dz. cyt., s. 218.

30 T. Narbutt, Dzieje starożytne narodu litewskiego, t. 2, Wilno 1837, s. 398.

31 I. Janke, Gaszenie pamięci, „Uważam Rze” 2011, nr 7, s. 12.

32 Cyt. za: A. Biernacki, dz. cyt., s. 310. Wpis sztambuchowy Adama Celińskiego.

33 D. Bończa Tomaszewski, Wyobraźnia i pamięć, w: tegoż, Pisma wierszem i proza, t. 1, Warszawa 1822 , s. 140 . 
Niemal identycznie rozprawia się z pamięcią Mickiewicz w Prologu do III części Dziadów. Oba teksty wpisują się w zdecydowanie przedromantyczną tradycję debaty o związkach i różnicach pomiędzy różnymi sferami umysłu. Zazwyczaj przedmiotem namysłu była tu triada rozum-wyobraźnia-pamięć, ale tu Mickiewicz konfrontuje ze sobą wyobraźnię, pamięć i marzenie senne. Ten oświeceniowy namysł bardzo dobrze widać między innymi w pismach braci Śniadeckich czy Euzebiusza Słowackiego. Wracamy w tym miejscu do kluczowej dla czasów przedromantycznych metafory pamięci jako pojemnika czy magazynu, wobec którego mnemotechniki pełnią funkcję regulującą czy porządkującą, wypracowywały bowiem sposoby na radzenie sobie z panującym w nim chaosem. Jeżeli zatem, jak Mickiewicz w Prologu, romantycy dyskredytowali pamięć, to zwykle odnosili się do tej właśnie idei pamięci, która w starciu z poetycką, wieszczą imaginacją od razu stawała na straconej pozycji. W myśleniu Mickiewicza ciągle jednak przewijają się co najmniej dwa typy czy rozumienia pamięci, mocno od siebie odgraniczone. Konrada Wallenroda nazywam „pamięciomatem” między innymi dlatego, że racją bytu tytułowego bohatera jest ustawiczne, nieskończone pamiętanie, zaś racją bytu najbliższych mu osób - przypominanie mu o tym, że ma pamięć. To ujęcie zbliża się w istotnych szczegółach do opisywanej przez Assmann pamięci w sensie vis.

W tym momencie możemy zwrócić się ku zdecydowanie mniej licznym - przynajmniej pod względem ich tekstowej reprezentacji - metaforom pamięci, odwołującym się do zjawisk ze sfery nowoczesności. Z poniższego zestawienia dałoby się wysnuć wniosek, że najlepszym tropicielem nowoczesności, osobą z najlepszym jej wyczuciem, a więc kimś, kto jest szczególnie wyczulony na nowoczesność, był Zygmunt Krasiński. Znajdujemy u niego przynajmniej trzy tak nacechowane metafory.

\section{(1) pamięć jako elektryczne spięcie, "stos galwanicznych pamiątek"}

Dzięki Ci, Dialy, że tak chowasz moje pamiąteczki, popiołeczki; i u mnie sto takich kiedyś odnajdziesz drobnostek olb r z y m i ch, począwszy od wstążeczki trzewika, zdjętej w parku Stefanii, aż do rękawiczek jedwabnych lugduńskich, wypranych Twą rączką w Sens, a w których wystąpię za pierwszym dniem szczęścia! Pierwsza w pularesiczku neapolitańskim, drugie czekają zmartwychwstania w pularesie w Bazylei mi danym; między tymi dwoma biegunami tego stosu galwanicznego pamiątek mieści się długi łańcuch, którego każde ogniwo mi drogim jest - darów Twoich tysiąc, szpileczek, sztychów, obrazeczków, małych bilecików, gdzie spojrzę, tam coś Twego, a gdy w siebie spojrzę, i ja też Twój! ${ }^{34}$

34 List z 16/17 marca 1844 roku, w: Z. Krasiński, Listy do Delfiny Potockiej, oprac. i wstęp Z. Sudolski, t. 2, Warszawa 1975, s. 365. 
Wstążeczka trzewika i rękawiczki jedwabne jako bieguny ogniwa Volty, złączone długim łańcuchem elektrod zanurzonych w elektrolicie - czy raczej, trzymając się poetyki listu - elektrodek w elektroliciku. Ten obraz pamięci do pewnego stopnia odpowiada niektórym najnowszym - neurologicznym - teoriom zapamiętywania, zgodnie z którymi ślad pamięciowy powstaje wskutek przechodzenia impulsu nerwowego z jednej komórki nerwowej do drugiej (i tak dalej) i związanymi z tym procesami chemicznymi zachodzącymi w dendrytach kolejnych komórek nerwowych.

\section{(2) pamięć jako magnetyzm lub siła magnetyczna}

Jak wiadomo, korespondencja Krasińskiego obfituje w odwołania do magnetyzmu. A ponieważ jedną z sił magnetycznych jest dla poety pamięć, przykładów tej metafory znajdziemy aż nadto. Krasiński chętnie mówi na przykład o „magnetyzmie wspomnienia” lub o magnetycznej „gorączce wspomnień”. Pamięć i wspominanie doskonale wpisują się w wypracowaną przez Krasińskiego formułę magnetyzmu, co widać chociażby w takiej jego definicji (jednej z wielu): „Stąd to siłą wewnętrzną ducha jest magnetyzm, bo magnetyzm skupia do jedni wszędzie gdzie indziej rozerwane czasu żywioły, jak przez oko widzenia stawia w teraźniejszości żywej wszystkie przeszłości i wszystkie przyszłości ${ }^{35}$.

\section{(3) pamięć jako dagerotyp}

Rzecz jasna, wynalazek Louisa Daguerre’a łączył precyzję zwierciadła i właściwie nieznaną wcześniej możność utrwalania odbicia. $Z$ tego powodu dagerotypia, a później fotografia, stanowiła dla pamięciowej metaforyki skok w zupełnie nową epokę i nową jakość. Co jednak ciekawe, w polskich tekstach, w których dagerotypia pojawia się w kontekście pamięci, nie zawsze wzbudza entuzjazm. Wynika to, jak sądzę, z dwóch zasadniczych powodów. Po pierwsze, z powątpiewania w aż tak cudowną moc pamięci. I tak Ryszard Berwiński w swoich Studiach o literaturze ludowej (1854), krytycznie odnosi się do poszukiwań jakiejś prastarej mitologii słowiańskiej i do wiary, że została ona wiernie zachowana w kolektywnej ludowej pamięci: „Lud przeto, raczej wrażebny umysł jego, nie jest na kształt płyty Daguerra, na której blaskiem słońca odbity raz obraz zewnętrzny utrwala się na zawsze i pozostaje niezmienny" ${ }^{36}$. Studia Berwińskiego, wraz z przedstawioną tu konstatacją, mogłyby posłużyć jako argument w sporze z psychoanalizą archetypową i z dzisiejszymi ba-

35 List z 21 grudnia 1843 roku, w: jw., s. 206.

36 R. Berwiński, Studia o literaturze ludowej ze stanowiska historycznej i naukowej krytyki, t. 2, Poznań 1854, s. 209. 
daniami pamięci zbiorowej. Drugi powód wiąże się z przeczuciem, że przedmiot utrwalony w światłoczułej warstwie na miedzianej płytce jedynie stwarza pozór życia. Kazimierz Władysław Wójcicki ujmuje to możliwie najtrafniej: „[...] pamiątki nasze wszystkie to są cienie tylko przyjaciół, których grób sprzed naszych porwał oczów; to są istne dagerotypy z[e] swym martwym podobieństwem" ${ }^{37}$.

Krasiński jest tymczasem zafascynowany dagerotypami i stara się je kolekcjonować:

Od dawna już w moim pokoju jest miejsce takie, Tobie poświęcone, drugi stolik cały, długi, ten, co prostopadle styka się ze stolikiem, na którym piszę, ołtarzem Twoim, tam same pamiątki Twoje. Dagierotyp Twój nicejski, św. Janowy, w aksamicie [....$^{38}$

Dagerotyp służy jednocześnie jako model opisujący wyobraźnię autora Irydiona:

Znudzę Cię na koniec wspomnieniami, ale natura moja jest naturą wspomnień. Gdy raz zaczną przesuwać się przez duszę moją, nie ma im końca. Idą jedne po drugich jak złote księżyce, jak zorze borealne, jak drogi mleczne, jak tęcz girlandy, zlane łzami mymi. - To ich świeżość! Staję się cały camera obscura, a przeszłość igra po mnie jak światło i w serce mi dagerotypuje szczęścia chwile szarym smutku blaskiem. Żebyś mogła wyjąć mi serce z piersi, obaczyłabyś na nim wyryte wszystkie miejsca, gdzieśmy byli razem - i katedrę niemiecką, i włoską katedrę, i kościół Piotra, i Neapolu brzegi, i Genui pałace, i Góry Alpejskie, i wzgórza Badenu, i wnętrze „Pfauna”, i dom Twój w Baden, i dom nasz w Mannheimie, i ten statek parowy na Renie. ${ }^{39}$

Równie ważną rolę w tym fragmencie odgrywa inny, znacznie starszy wynalazek. Niewykluczone, że Krasiński nawiązuje tu do odkrycia, którego jeszcze przed Daguerre'em dokonał Joseph Niépce, autor pierwszych zdjęć z użyciem camera obscura. Traktat Bronisława Trentowskiego Myślini (1844) zawiera, przynajmniej na pierwszy rzut oka, bardzo zbliżone zestawienie camera obscura i dagerotypu; zestawienie to nie pozostaje bez związku z pamięcią:

Pamięć jest zmysłem i wyobraźnią wyższej potęgi; jest władzą zamrażania płynnych wyobrażeń w jaźni; ujmowaniem na tym polu, że tak rzekę, ulotnego słowa w sto-

37 K.W. Wójcicki, Historia literatury polskiej w zarysach, t. 4, Warszawa 1861, s. 429. Osąd Wójcickiego można wszelako skonfrontować z takim chociażby, jakże odmiennym w wymowie, sformułowaniem wyjętym z Dziejów artystycznej fantazji Józefa Kremera: „[...] ten artysta to istny dagerotyp w postaci żywego człowieka” (J. Kremer, Listy z Krakowa, t. 2: Dzieje artystycznej fantazji, cz. 1, Wilno 1855, s. 156).

38 List z 31 grudnia 1843 roku, w: Z. Krasiński, dz. cyt., s. 227. Widzimy przy okazji, że mamy tu kolejną wersję świątyni pamięci - a mianowicie ołtarz(yk) pamięci.

39 List z 8/9 stycznia 1840 roku, w: Z. Krasiński, Listy do Delfiny Potockiej, oprac. i wstęp Z. Sudolski, t. 1, Warszawa 1975, s. 132-133. 
jącą i nieruchomą piśmienną literę. Jeżeli wyobraźnia ma podobieństwo do oświetlonego blaskiem przedmiotów tła in camera obscura, to pamięć jest fabrykantką stałych dagerotypów. ${ }^{40}$

Wyobraźnia to u Trentowskiego rodzaj zmysłu wewnętrznego, który percepcje zmysłów zewnętrznych, czyli wrażenia, przekształca w wyobrażenia. Wyobraźnia nie jest tu rozumianą romantycznie imaginacją, jak to było w Prologu do III części Dziadów. Stąd porównanie wyobraźni do camera obcsura, która wytwarza „wierne rzeczy wyobrażenia”, ale nie potrafi ich zatrzymać. Jaźń jest konfrontowana z mnogością przedstawień, z „galerią obrazów”, które wymagają dopiero udziału dagerotypii, to znaczy pamięci, która radzi sobie z tym niedomaganiem wyobraźni. Istnieje wszakże istotna różnica pomiędzy ujęciami Krasińskiego i Trentowskiego, która z grubsza polegałaby na tym, że u drugiego z nich wyobraźnia i pamięć są władzami wyłącznie zmysłowymi; pamięć należy „nie do umysłowości, nie do duszy, ale do zmysłowości, do ciała” ${ }^{\text {. }}$ Rozpoznajemy tu dziedzictwo Arystotelesa, który w traktacie O pamięci i przypominaniu sobie traktuje oba tytułowe fenomeny jako części duszy zmysłowej i wiąże je z cielesnością.

\section{(4) pamięć jako kalejdoskop}

Urządzenie to pojawia się w omawianym tekście Trentowskiego ${ }^{42}$. Kalejdoskop został wynaleziony w 1816 roku. Jak łatwo się domyślić, ilekroć zostaje przywołany jako exemplum, to głównie po to, by wyakcentować przypadkowość, z jaką wspomnienia łączą się w większe zbiory i konstelacje. Pamięć przedstawiana za pomocą metafory kalejdoskopu byłaby zatem - zgodnie z określeniem wspominanego już tutaj Michała Wiszniewskiego - „niewstrzymana w biegu”, taka, która „[...] wyprowadza roje myśli i wyobrażeń, które tłumami się cisnąc, nawzajem wypychając, żadnego po sobie nie zostawują śladu" ${ }^{3}$. Dodać należy, że ten opis fenomenu pamięci został włączony do charakterystyki człowieka roztargnionego: gdyby ów „głośno myślał albo gdyby na przemijające ciągle i ciągle przetwarzające się, jak figury w kalejdoskopie, myśli jego patrzyć się można, każdy by rozumiał, iż dostał pomieszania" ${ }^{44}$.

B. Trentowski, Myślini, czyli całokształt logiki narodowej, t. 1, Poznań 1844, s. 330.

41 Tamże, s. 330-331.

42 „Oczy nasze są zaiste najwyborniejszymi kalejdoskopami!” (tamże, s. 330).

43 M. Wiszniewski, dz. cyt., s. 99.

44 Tamże. 
(5) pamięć jako zobowiązanie finansowe

(kredyt, pożyczka)

Zacznę od sztambuchowego wpisu Ludwika Kondratowicza (Władysława Syrokomli), który warto zacy tować w całości:

Człek kocha ludzi i marzy

Być pokochanym nawzajem -

Więc często na kształt kramarzy

Uczucia na kredyt dajem:

Licząc na serca współbraci,

Że się wzajemność wypłaci.

A iż się pismem stanowi Jakaś na przyszłość otucha, Mówimy przyjacielowi

Dając mu kartkę sztambucha:

„Niech to waszmości nie drażni

Wpisz tu cyrograf przyjaźni!”.

Lecz pytam: Co znaczy księga?

Co znaczy pamięć dłużnika?

Wpisze się, zaklnie, przysięga,

A potem jak w wodę znika -

Tylko ślad czarno na białym,

Że oszukany zostałem;

Tylko żal próżny po stracie I skarga na ród człowieczy;

My z Tobą, panie Donacie,

Nie tak urządzim te rzeczy!

Nim przyjaźń powoli wzrasta

Szacujmy siebie i basta!

A resztę dopełnią lata

(Nic nie przyrzekam, lecz wróżę)

Ja Cię pokocham jak brata,

Kochaj mię, jeśli zasłużę;

Tak sobie, szczerzy a prości,

Ufajmy dobrej przyszłości. ${ }^{45}$

Metafora, której tu się używa, mogłaby zostać określona w kategoriach pożyczki, kredytu albo długu - do spłacenia w mniej lub bardziej określonym terminie. Na pierwszy rzut oka wydaje się, że to myślenie o pamięci jest nader tradycyjne i do tego dobrze zakorzenione w historii języka. Chętnie bowiem mawiamy o „długu przyjaźni” czy „długu pamięci” - i oczywiście tego rodzaju

45 Cyt. za: A. Biernacki, dz. cyt., s. 340-341. 
określenia istniały w polszczyźnie (i nie tylko w polszczyźnie) na długo przed Syrokomlą. Co więcej, przytoczony wiersz jest utrzymany w typowej dla jego autora poetyce ironii, żartu, rubasznego czy jowialnego humoru i można by z tego powodu uznać, że nic poważnego się tutaj nie mówi. Sądzę, że jest zgoła inaczej. Są bowiem dowody, że w tym wierszu toczy się intrygujący bój między tradycją a nowoczesnością, że dochodzi tu do głosu nowa, burżuazyjna czy kapitalistyczna (w rozumieniu Karola Marksa) forma świadomości społeczno-ekonomicznej. Nie przypadkiem Kondratowicz - pod tym nazwiskiem wpisał się do pamiętnika w marcu 1853 roku - wykracza poza tradycyjną i uświęconą formułę „długu pamięci” i porównuje pamięć z kredytem, czyli zobowiązaniem o charakterze stricte finansowym. Zobowiązanie ekonomiczne zakłada stopę zwrotu, zysk, marżę, na której można coś zarobić, ale obarczone jest też ryzykiem obustronnego oszustwa czy nadużycia i potencjalnym niepowodzeniem w formie straty. Zwyczajny „dług pamięci” albo „dług przyjaźni” nie jest niczym więcej niż zobowiązaniem wynikającym z bliskich relacji, a więc etyką pamięci w rozumieniu Avishaia Margalita ${ }^{46}$, przy czym nawet owo nieekonomiczne rozumienie powiązane jest z pojęciami lojalności i zdrady, a sama kategoria „długu pamięci” wystarczyłaby, żeby mówić o osobnym typie metaforyki pamięci.

„Że się wzajemność wypłaci” to jednak zobowiązanie zupełnie innego rodzaju, bo naznaczone nadzieją potencjalnego zysku. Przywołałem język Marksa nieprzypadkowo: to on w swoich Rękopisach ekonomiczno-filozoficznych $z 1844$ roku zwrócił uwagę na fakt, że w ekonomii kapitalistycznej nie istnieją dobra, które nie byłyby policzalne i przeliczalne na ekwiwalent pieniężny. Potrzeba zysku jest jedyną siłą napędową społeczeństwa kapitalistycznego (a ściślej rzecz ujmując - wąskiej grupy kapitalistów), co z kolei sprawia, że wartość pieniężna staje się jedynym spoiwem relacji społecznych i ich wyłącznym miernikiem:

Jeśli pieniądz jest więzią, która wiąże mnie z życiem ludzkim, ze społeczeństwem, z przyrodą i ludźmi, to czyż nie jest on więzią wszystkich więzi? Czyż nie potrafi rozwiązywać i zawiązywać wszelkich więzi? Czyż nie jest zatem również powszechnym środkiem separacji? Jest on prawdziwą moneta zdawkową, jak i prawdziwym środkiem wiążacym, [powszechną] chemiczną siłą społeczeństwa. ${ }^{47}$

Mniej więcej zbliżoną wizję, jedynie ukrytą pod „czerepem rubasznym”, prezentuje Syrokomla. Niepoważnie mówi o tym, co poważne. Pamięć, która

46 Zob. A. Margalit, The Ethics of Memory, Cambridge-London 2004.

47 K. Marks, Rękopisy ekonomiczno-filozoficzne z 1844 r., przeł. K. Jażdżewski i T. Zabłudowski, w: K. Marks, F. Engels, Dzieła, t. 1, Warszawa 196o, s. 612. 
dla romantyków jest świętością, tutaj jest tylko przejawem ekonomicznego obrachunku, a więc zgodnie z tezą Marksa, staje się przedmiotem zawłaszczenia przez nową formułę świadomości ekonomicznej, dla której nie istnieje wartość nie-rynkowa oraz nie-pieniężna. Jednocześnie dochodzi w tym wierszu do głosu Hobbesowsko-Smithowska wizja jednostki ludzkiej: działającej z pobudek egoistycznych, z nadzieją na możliwie największy zysk ${ }^{48}$. Relacjami międzyludzkimi rządzi tu nie jakaś miła i sympatyczna wzajemna życzliwość, ale ekonomiczny kontrakt. Jak gdyby przepowiadało się tutaj narodziny Gordona Gekko, który przekonywał, że „chciwość - z braku lepszego określenia - jest dobra" ${ }^{49}$.

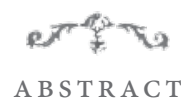

\section{Romantic Metaphors of Memory}

Romanticism is often associated with a turning point in how memory was perceived and comprehended. This turn, according to some commentators, should be linked with the birth of modernity. The article presents and regroups Polish Romantic "metaphors of memory," in a sense given to that notion by Douwe Draaisma. The classification shows quite clearly that only in a few cases Polish authors managed to move away from the traditional and well-known categorizations and relying on modernity and technical innovations would not necessarily entail the abandonment of tradition and history. However, even in those rare situations they proved to be sensitive to changes in civilisation and society.

\section{KEYWOR D S}

memory, Romanticism, metaphors of memory, cultural memory, Draaisma

48 Marks streszcza tę ideę Adama Smitha następująco: „Motywem wymiany nie jest humanitarność, lecz egoizm" (tamże, s. 606).

49 Główny bohater filmu Wall Street Olivera Stone’a (1987). Pełne zdanie w oryginale brzmi następująco: „The point is, ladies and gentlemen, that greed, for lack of a better word, is good". 